\title{
SARANG TERSEMBUNYI, HUTAN MENGKATIP
}

\author{
Lorenzo Alberto ${ }^{1)}$, J.M.Joko Priyono ${ }^{2 l}$ \\ 1) Program Studi S1 Arsitektur, Fakultas Teknik, Universitas Tarumanagara, Lorenzoalberto131@gmail.com \\ 2)Program Studi S1 Arsitektur, Fakultas Teknik, Universitas Tarumanagara, jokop@ft.untar.ac.id
}

Masuk: 21-01-2021, revisi: 21-02-2021, diterima untuk diterbitkan: 26-03-2021

\begin{abstract}
Abstrak
Hutan memiliki peranan yang penting dalam memenuhi kebutuhan hidup manusia , namun karena kurangnya pendidikan serta banyaknya pihak yang tidak bertanggung jawab, kawasan hutan justru mengalami eksploitasi besar-besaran di seluruh dunia. Di Indonesia sendiri tutupan lahan hutan sudah banyak berkurang, Kalimantan merupakan salah satu daerah yang paling terdampak dari deforestasi. Menurut hasil Riset pada tahun 2015 sekitar 74 juta Ha tutupan hutan telah berkurang menjadi 55\% serta angka deforestasi yang terjadi di Kalimantan terus meningkat. Mengkatip Forest, Hidden Nest hadir sebagai wadah bagi masyarakat yang terlibat dalam kasus deforestasi di Kalimantan,dan dari hasil data yang telah diperoleh dibuatlah pendekatan dengan metode gradasi spasial dimana pendekatan ini melibatkan seluruh elemen masyarakat didalamnya. Proyek ini sendiri bertujuan untuk menciptakan hubungan mutualisme antara masyarakat serta mahluk hidup yang tinggal didalamnya. Program-program yang dibuat pada kawasan proyek ini menjadi sebuah upaya untuk mencegah kerusakan hutan yang lebih lanjut dan memulihkan kembali kawasan hutan yang rusak serta menjaga lingkungan hutan berdasarkan konsep 'Antroposmotic' suku Dayak.
\end{abstract}

Kata kunci: Antroposmotic ;Deforestasi ;Mutualisme

\begin{abstract}
Forests have an important role in meeting the needs of human life, but due to lack of education and irresponsible parties, forest area is now undergone massive exploitation all around the world. In Indonesia, forest cover has been reduced by a lot, Kalimantan is one of the areas that are most affected by deforestation. According to research results in 2015, approximately 74 million ha of forest cover has been reduced to $55 \%$ and deforestation rates in Kalimantan continue to increase. Mengkatip Forest, Hidden Nest is present for people that is involved in deforestation cases in Kalimantan, and from the result of the data that has been obtained a spatial gradation method is made in which this approach involves all elements of society in it. The project itself aims to create a mutualism relationship between the community and the living beings who live in it. The programs created in this project is an effort to prevent further damage in the forest and restore the damaged areas while maintaining the forest environment based on the concept of the 'Anthroposmotic' Dayak tribe.
\end{abstract}

Keywords: Anthroposmotic;Deforestation;Mutualism

\section{PENDAHULUAN Latar Belakang}

Maraknya isu yang sedang terjadi secara global saat ini adalah pembabakan hutan yang dilakukan oleh aktivitas manusia dan didukung oleh teknologi yang terus berkembang. Deforestasi mengakibatkan diversitas alternatif berbagai kegiatan termasuk membuka lahan baru sebagai tempat tinggal dan berbagai macam usaha. Kegiatan deforestasi di Indonesia paling besar mengarah kepada sektor industri terutama kayu, yang banyak menyalahgunakan fungsi HPH. Penebangan 
hutan di Indonesia pada saat ini mencapai 40 juta meter kubik setahun, sedangkan laju penebangan sustainable yang direkomendasikan oleh Departemen Kehutanan adalah 22 juta kubik meter setahun. Berdasarkan dari data yang diperoleh di Indonesia pada tahun 2016-2017 (Mongabay Indonesia), pulau dengan tingkat deforestasi paling besar terjadi di Kalimantan yaitu 229,8 ribu Ha, Sumatra 127 ribu Ha, Sulawesi 70,8 ribu Ha, dan Papua yaitu 48,6 ribu Ha. Di Kalimantan sendiri tingginya laju deforestasi merupakan akibat dari besarnya dorongan pembuatan bubur kertas dan kelapa sawit menunjukkan ancaman bagi berbagai komunitas yang tinggal di dalamnya termasuk suku Dayak. Kalimantan Tengah mengalami dampak dari deforestasi paling besar di antara wilayah lainnya sehingga menjadi fokus perbaikan. Menanggapi permaslahan di atas maka diusulkan sebuah proyek forestrasi dalam bentuk penyuluhan dan pilot project dwelling di Mengkatip,Kalimantan Tengah. Laporan ini juga akan membahas tahapan-tahapan yang dilakukan pada saat melakukan pemilihan isu yang akan diangkat sebagai latar belakang dalam mendesain proyek.

\section{Rumusan Permasalahan}

a. Mungkinkah menyandingkan sebuah dwelling yang bebas dari keterlibatan Deforestasi.

b. Mungkinkah menciptakan sebuah Dwelling yang mampu menjadi percontohan untuk menumbuhkan jiwa forestrasi.

c. Mungkinkah dwelling ini mampu berkontribusi untuk menurunkan Global warming.

\section{Tujuan}

proyek ini diharapkan menjadi percontohan pengembangan dwelling di Hutan Indonesia, untuk meningkatkan kesadaran penghijauan di tengah-tengah maraknya Deforestasi dan isu Global warming.

\section{KAJIAN LITERATUR}

\section{Teori Dwelling Menurut Christian Norberg-Schulz}

Dalam bukunya yang berjudul The Concept of Dwelling, menurutnya ada 2 hal penting mengenai arti dwelling. Yaitu dwelling atau berhuni adalah suatu tempat yang berguna untuk bertukar ide, perasaan maupun produk demi mendapatkan suatu pengalaman. Yang kedua, dwelling adalah suatu tempat untuk mencapai kesepakatan.

\section{Teori Dwelling Menurut Martin Heidegger}

Dalam bukunya yang berjudul Building, Dwelling, Thinking, Heidegger mengatakan bahwa dwelling memiliki hubungan erat dengan ruang hidup manusia tetapi tidak hanya sekedar manusia kemudian hal ini dibagi menjadi 3 komponen yaitu earth, sky, dan divinities. Menurut Heidegger, Dwelling merupakan konsep dalam menghuni yang berhubungan dengan berkelana dan menetap. Menurut Martin Heidegger, Dwelling ini berasal dari kata "dwellan" yang berarti berkelana dan menetap (bertahan hidup) diartikan bahwa untuk bertahan hidup di suatu tempat tidak harus menetap melainkan lebih baik untuk mengembara.

\section{Sustainable Design}

Sustainable Design merupakan jenis design yang hanya menggunakan sumber daya terbarukan sebagai materialnya. Selain itu tujuan dibuatnya design berkelanjutan ini adalah untuk meminimalkan dampak yang diberikan pada lingkungan dari hasil deforestasi baik Ketika dibuat ataupun digunakan. Pada rancangan ini memungkinkan pengguna merasakan atau terhubung lebih dekat dengan lingkungan alam. Berikut prinsip-prinsip umum yang dipegang dalam membangun 'Sustainable Design' :

a. Low-impact material : Memanfaatkan bahan non-toxic dan diproduksi secara ramah lingkungan.

b. Efisiensi energi : Menggunakan atau membuat produk yang hanya membutuhkan sedikit energi. 
c. Kualitas dan daya tahan : Produk yang berfungsi baik secara lama berarti mengurangi perawatan atau penggantian.

d. Reuse and recycle : Rancangan produk harus mempertimbangkan pemanfaatan secara berkelanjutan hingga setelah masa pakai.

e. Renewability : Bahan berasal dari wilayah terdekat, diproduksi dari sumberdaya terbarukan, serta bisa diolah menjadi kompos.

f. Sehat : Produk tidak berbahaya bagi pengguna dan lingkungan sekitarnya, bahkan bisa menunjang aspek kesehatan secara luas.

\section{Elemen Pembentuk Citra Kawasan / Kota Menurut Kevin Lynch}

Pembuatan dwelling ditengah - tengah hutan tentunya akan sulit, terutama karena susahnya akses, kontur yang tidak rata dan jauh dai fasilitas umum. Untuk membuat proyek terlihat lebih dominan ditengah-tengah hutan ini maka banyak aspek yang perlu diperhatikan. Menurut Kevin Lynch untuk menciptakan branding suatu kota maka diperlukan gambaran khas pada kota yang mampu menjadi representasi bagi penduduk maupun pengunjung. Aspek fisik kota biasanya mampu mempengaruhi citra kota. Didalam buku image of the city, Kevin Lynch dapat ditemukan 5 elemen fisik yang dapat membentuk sebuah kota. Elemen-elemen ini dapat mewakili identitas dari suatu Kawasan dan memberikan citra yang kuat pada kota, selain itu tujuan dari ke-lima elemen ini adalah untuk memudahkan elemen fisik yang ada pada suatu Kawasan/kota. Berikut penjelas elemen-elemen pembentuk kota menurut teori Kevin Lynch :

\section{a. Jalur (Path)}

Merupakan jalur dimana biasanya pengamat bergerak. Menurut Lynch, Path merupakan aspek penting dalam membenuk sebuah citra Kawasan, karena jika tidak jelas maka kebanyakan orang akan bingung dan ragu terhadapat citra kota tersebut. Semaikin jelas tujuannya maka identitas dari jalur ini akan lebih terlihat.

\section{b. Tepian (Edges)}

Merupakan batas-batas antar wilayah sehingga tidak digunakan sebagai sebuah jalur. Biasanya merupakan sebuah penghalang walaupun terkadang ada akses untuk masuk. Edge juga menjadi pengakhiran bagi sebuah distrik,lebih baik jika dibuat lebih jelas.

\section{c. Distrik (District)}

Merupakan sebuah Kawasan kota yang memiliki skala menengah-luas, dimana manusia dapat merasakan keluar-masuk dari Kawasan yang berbeda. Distrik juga dikenali wilayah yang memiliki kesamaan dan mudah dikenali jika batasanya dibuat semakin jelas.

\section{d. Simpul (Nodes)}

Merupakan titik dalam sebuah kota yang fokus untuk ke dan berjalan. Setiap nodes memiliki bentuk yang berbeda, Semakin jelas tempatnya maka identitasnya akan semkain terlihat.

\section{e. Penanda (Landmark)}

Merupakaan titik acuan suatu kota, dimana orang tidak masuk karena bisa dilihat dari luar bentuknya. Landmark biasanya merupakan bentuk yang menonjol dari sebuah kota.

\section{METODE}

Metode penelitian yang digunakan dalam proyek adalah teknik Komparasi dan kualitatif. Langkahlangkah ini termasuk studi kasus mengenai lokasi tapak dan data-data yang berkaitan dengan subyek yang diteliti. Berikut penjelasan Teknik pengumpulan data yang digunakan :

\section{Metode Kualitatif}

Merupakan metode penelitian yang lebih menekankan tentang aspek pemahaman yang lebih mendalam mengenai suatu masalah. pada metode kualitatif metode yang digunakan adalah Teknik analisis mendalam, yaitu dengan mengkaji suatu masalah satu persatu, karena sifat dari suatu masalah dengan yang lainnya akan berbeda-beda. 


\section{Metode Komparasi}

Penelitian dengan 2 variabel atau lebih untuk membandingkan serta mengetahui perbedaan antara 2 kelompok atau lebih. Pada proyek ini penerapan teknik komparasi digunakan pada studi kasus untuk perbandingan data dari internet maupun lembaga milik pemerintahan.

\section{Metode Overlay}

Adalah teknik yang digunakan untuk menempatkan sebuah peta grafis diatas peta lainnya untuk membentuk sebuah peta gabungan. Teknik ini digunakkan untuk mencari lokasi site yang sesuai dengan isu deforestasi yang diambil.

Jenis data yang digunakan pada penelitian merupakan data sekunder dimana data yang diambil berasal dari data yang sudah ada, berikut uraian data yang diperoleh :

\section{- Studi Pustaka}

Tujuan dari studi pustaka adalah untuk mendapatkan data-data yang dibutuhkan, baik dari teori, pendapat ahli, serta peraturan dan kebijakan pemerintah yang dapat dijadikan dasar perencanaan sehingga dapat memperdalam analisa. Berikut data yang diperoleh:

a) Data atau literatur tentang tapak terpilih berupa peta wilayah, dan potensi alam. Data ini kemudian selanjutnya digunakan untuk menganalisis kawasan tapak.

b) Literatur mengenai deforestasi beserta dampak dan penyebabnya. Data ini akan digunakan untuk menganalisa konsep

c) Data literatur mengenai pola persebaran dan gaya hidup masyarakat dayak dalam hutan, sebagai acuan untuk menganalisa ruang maupun konsep ruang

\section{DISKUSI DAN HASIL}

\section{Analisa Kawasan}

Setelah mengetahui bahwa seluruh elemen dan sektor terbesar penyumbang emisi gas rumah kaca adalah deforestasi, maka ditentukanlah wilayah yang memiliki frekuensi kerusakan hutan paling banyak dan didapatkan bahwa wilayah Kalimantan Tengah memiliki jumlah kehilangan tutupan hutan yang sangat tinggi kemudian diambilah lokasi tapak yang sudah ditentukan yaitu di Desa Mengkatip, Kec. Dusun Hilir. Area di sekitar tapak banyak didominasi oleh lahan kritis akibat dari pembukaan lahan baru serta lahan gambut dan rawa-rawa. Selain itu, tapak terletak di sebelah selatan sungai barito dimana sungai menjadi Batasan admministrasi sebelah Utara site; di sebelah timur berbatsan dengan area penggunaan lain; di sebelah barat tapak berbatasan dengan area Kawasan Suaka Alam; dan yang terakhir di bagian Selatan tapak merupakan lahan dengan fungsi pemukiman yang masih kosong.

\section{Kapasitas Kawasan}

Perhitungan kawasan proyek berdasarkan hasil dari tinggi rendahnya kepadatan penduduk. Kelurahan Mengkatip memiliki 5 RW dengan luas kawasan kurang lebih $140 \mathrm{Ha}$. Luas tapak yang digunakan adalah 19 Ha,dengan memaksimalkan KDH yang ada menjadi $40 \%$ serta mempertimbangkan rata-rata jumlah penduduk setiap RW untuk proyek kawasan ,maka hasil perhitungan yang dibuat harus bisa menampung $60 \mathrm{kk}$ untuk proyek huniannya.

\section{Analisa Program}

Pembentukan program pada site dibuat berdasarkan hasil analisa serta pendekatan yang dilakukan untuk menyelesaikan konflik penyebab deforestasi yang terjadi di kawasan Mengkatip. Poin awal dari pembuatan program didasari dari aktivitas serta kebutuhan masyarakat dayak serta developer akan sumber daya yang ada di Hutan, agar dapat menciptakan hubungan mutualisme antar subyek. 


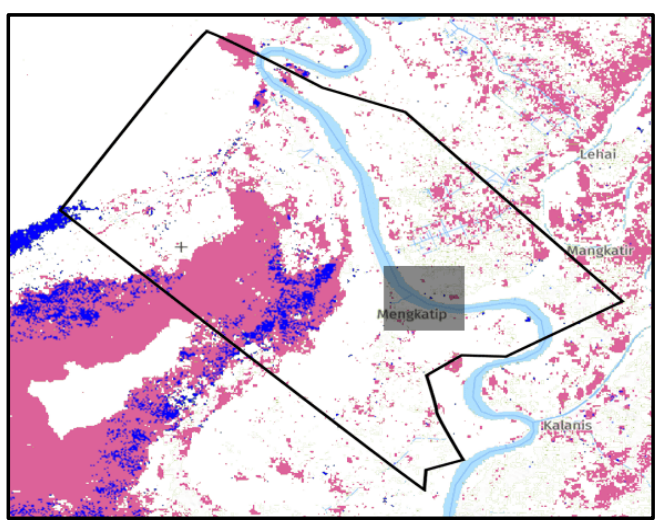

Gambar 1. Peta deforestasi di Mengkaip

Sumber:www.globalforestwatch.org

Berikut adalah beberapa pendekatan yang dibuat untuk untuk tiap masalah yang terjadi di kawasan :

\section{a. Advokasi}

Merupakan tindakan yang dilakukan oleh individu atau kelompok untuk mempengaruhi atau mengubah sebuah keputusan.

\section{b. Integrasi}

Menurut Yron Weiner Integrasi merupakan sebuah proses untuk menggabungkan berbagai kelompok budaya menjadi satu unit untuk pembentukan sebuah identitas.

\section{c. Support}

membuat peraturan yang mampu disepakati dan membantu diharapkan dapat menciptakan kesepakatan antara ketiga pihak.

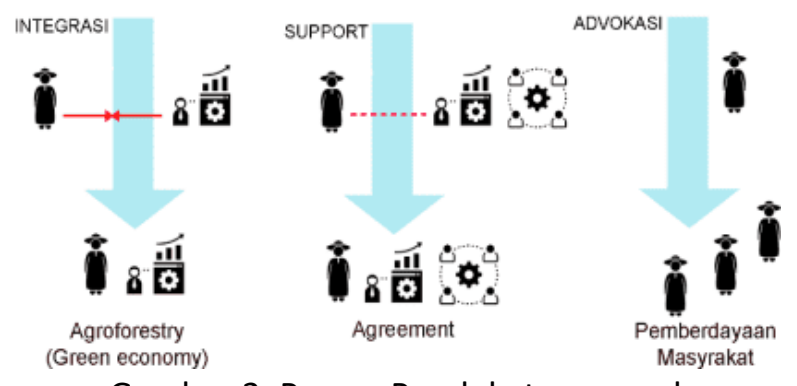

Gambar 2. Proses Pendekatan proyek

Sumber:Penulis, 2020

\section{Penerapan Program dalam Perancangan}

Pendekatan pada rancangan yang telah dibuat tersebut kemudian di wujudkan dengan menciptakan tingkatan pada ruang (gradasi spasial) untuk menjembatani perbedaan antara suku Dayak dengan pendatang agar mampu menciptakan sebuah ruang netral bagi masyarakat.

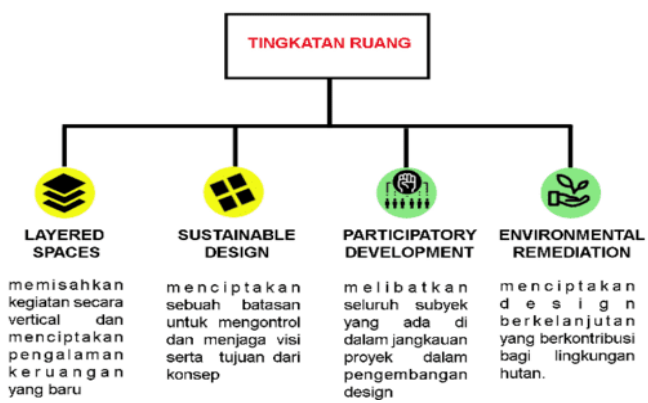

Gambar 3. Penerapan desain Sumber:Penulis, 2020 


\section{Usulan Desain berdasarkan Konsep Tingkatan Ruang}

Penggunaan konsep dari 'SPATIAL GRADIATION' ini adalah untuk menyesuaikan atau mengabungkan berbagai aktivitas yang terjadi di antara beberapa subyek sehingga tercipta sebuah zoning yang mampu menyesuaikan kegiatan masyarakat di area yang ditentukan.

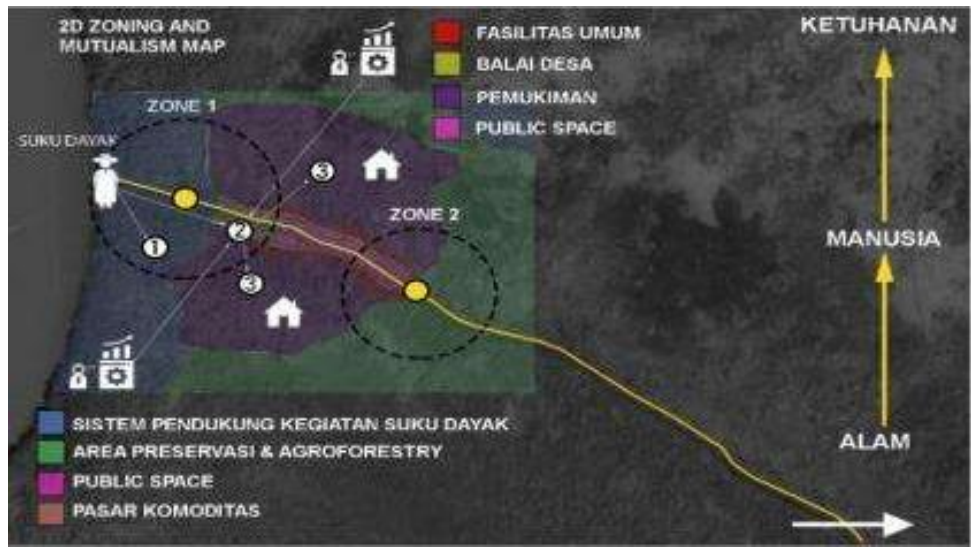

Gambar 4. Zoning berdasarkan tingkatan ruang Sumber:Penulis, 2020

Hasil dari konsep tingkatan ruang ini adalah menciptakan hubungan mutualisme antar subyek diantaranya adalah :

a. Penerapan kegiatan berladang suku dayak dan aktivitasnya dalam site berpotensi menarik turis.

b. Kegiatan komersial yang terjadi pada pasar disuplai dan diatur langsung oleh komunitas Dayak

c. Material yang digunakan pada bangunan menggunakan kayu dan bamboo yang berasal dari pengrajin lokal sehingga mampu membuka lapangan pekerja baru dann produktivitas masyarakat setempat.

\section{Program Ruang}

Kebutuhan ruang di kawasan Mengkatip dibagi menjadi 2 kategori berdasarkan kelompok kegiatannya. Berikut adalah tabel kebutuhan ruang yang diperlukan masing-masing fungsinya:

\section{- Area Kegiatan Utama}

Tabel 1. Tabel Program Ruang Kawasan Hunian

\begin{tabular}{|c|c|c|c|c|c|c|}
\hline & PROGRAM KEGIATAN & USER & KEGIATAN & RUANG & KAPASITAS & LUASAN \\
\hline \multirow{4}{*}{ 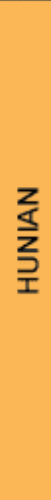 } & TIPE $1 \mathrm{KT}$ & $\begin{array}{l}\text { - Pemilik } \\
\text { Rumah } \\
\text { - Tamu }\end{array}$ & $\begin{array}{l}\text { Makan, Tidur, } \\
\text { mandi/wc, bekerja, } \\
\text { istirahat, berkumpul } \\
\text { Menerima tamu, } \\
\text { nonton. }\end{array}$ & $\begin{array}{l}\text { - R.Keluarga } \\
\text { - K.Mandi } \\
\text { - K.Mandi Utama } \\
\text { - K.Tidur Utama } \\
\text { - Dapur } \\
\text { - Gudang }\end{array}$ & 1-2 Orang & $\begin{array}{c}12 \mathrm{~m}^{2} \\
4,5 \mathrm{~m}^{2} \\
6 \mathrm{~m}^{2} \\
16 \mathrm{~m}^{2} \\
4 \mathrm{~m}^{2} \\
4 \mathrm{~m}^{2}\end{array}$ \\
\hline & \multicolumn{5}{|c|}{ TOTAL + SIRKULASI 20\% } & $55,8 \mathrm{~m}^{2}$ \\
\hline & TIPE 2 KT & $\begin{array}{l}\text { - Pemilik } \\
\text { Rumah } \\
\text { - Tamu }\end{array}$ & $\begin{array}{c}\text { Makan, Tidur, } \\
\text { mandiwwc, bekerja, } \\
\text { istirahat, berkumpul } \\
\text { Menerima tamu, } \\
\text { nonton. }\end{array}$ & $\begin{array}{l}\text { - R.Keluarga } \\
\text { - K.Mandi } \\
\text { - K.Mandi Utama } \\
\text { - K.Tidur Utama } \\
\text { - K.Tidur } 2 \\
\text { - Dapur } \\
\text { - Gudang }\end{array}$ & 4-5 Orang & $\begin{array}{c}12 \mathrm{~m}^{2} \\
4,5 \mathrm{~m}^{2} \\
6 \mathrm{~m}^{2} \\
16 \mathrm{~m}^{2} \\
9 \mathrm{~m}^{2} \\
4 \mathrm{~m}^{2} \\
4 \mathrm{~m}^{2}\end{array}$ \\
\hline & \multicolumn{5}{|c|}{ TOTAL + SIRKULASI 20\% } & $66,6 \mathrm{~m}^{2}$ \\
\hline
\end{tabular}

Sumber:Penulis, 2020

Sintesa :

a. R.Makan dan Keluarga dapat dijadikan satu untuk memenuhi kebiasaan penghuni yang makan sambil menonton ataupun berkumpul.

b. R.Tamu dan Keluarga dijadikan satu untuk menghemat ruang yang digunakan. 


\section{- Area Kegiatan Penunjang}

Tabel 2. Tabel Program Ruang Kegiatan Penunjang

\begin{tabular}{|c|c|c|c|c|c|c|}
\hline & PROGRAM KEGIATAN & USER & KEGLATAN & RUANG & KAPASITAS & LUASAN \\
\hline \multirow[t]{2}{*}{$\frac{\frac{5}{c}}{\frac{5}{4}}$} & $\begin{array}{l}\text { BALAI } \\
\text { PENYULUHAN } \\
\text { FESTIVAL ADAT }\end{array}$ & $\begin{array}{l}\text { - Pengurus } \\
\text { Desa } \\
\text { - Karyawan } \\
\text { - Pengunjung }\end{array}$ & $\begin{array}{c}\text { Berkumpul, } \\
\text { Diskusi, Sosialisasi, } \\
\text { Menonton, Acara } \\
\text { Adat, }\end{array}$ & $\begin{array}{l}\text { - Pendhopo } \\
\text { - Kantor Balai Desa } \\
\text { - KMandi Umum }\end{array}$ & $\begin{array}{c}100 \text { Kursi }(1,4 \\
\left.\times 0,6 \mathrm{~m}^{2} / \text { kursi }\right) \\
1 \text { Unit } \\
2 \text { Unit }\end{array}$ & $\begin{array}{c}100,8 \mathrm{~m}^{2} \\
120 \mathrm{~m}^{2} \\
9 \mathrm{~m}^{2}\end{array}$ \\
\hline & \multicolumn{5}{|c|}{ TOTAL + SIRKULASI $30 \%$} & $298,74 \mathrm{~m}^{2}$ \\
\hline \multirow[t]{2}{*}{$\frac{\frac{w}{5}}{\frac{\pi}{0}}$} & $\begin{array}{l}\text { BALAI EDUKASI } \\
\text { WORKSHOP }\end{array}$ & $\begin{array}{l}\text { - Pengunjung } \\
\text { - Gura } \\
\text { - Staff }\end{array}$ & $\begin{array}{c}\text { Berinteraksi, } \\
\text { Berdiskusi, } \\
\text { Menonton, Briefing. } \\
\text { kegiatan mengajar } \\
\text { dan belajar, Kerja } \\
\text { Praktik, Membaca, } \\
\text { Presentasi, } \\
\text { Persiapan Studio } \\
\text { Workshop, } \\
\text { Menyimpan } \\
\text { Peralatan, Bermain }\end{array}$ & $\begin{array}{l}\text { - R.Kelas \& } \\
\text { Studio Workshop } \\
\text { - R.Pameran } \\
\text { - Gudang Alat } \\
\text { - Playground } \\
\text { - K.Mandi Umum }\end{array}$ & $\begin{array}{l}3 \text { Unit (8x12) } \\
1 \text { Unit } \\
1 \text { Unit } \\
1 \text { Unit } \\
2 \text { Unit }\end{array}$ & $\begin{array}{l}345,6 \mathrm{~m}^{2} \\
36 \mathrm{~m}^{2} \\
40 \mathrm{~m}^{2} \\
100 \mathrm{~m}^{2} \\
9 \mathrm{~m}^{2}\end{array}$ \\
\hline & \multicolumn{5}{|c|}{ TOTAL + SIRKULASI $30 \%$} & $689.78 \mathrm{~m}^{2}$ \\
\hline
\end{tabular}

Sumber:Penulis, 2020

\begin{tabular}{|c|c|c|c|c|c|c|}
\hline \multirow[t]{2}{*}{ 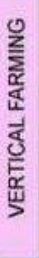 } & $\begin{array}{l}\text { MARKET AREA } \\
\text { FARMING AREA } \\
\text { MARKET AREA } \\
\text { SERVICE }\end{array}$ & $\begin{array}{l}\text {-Pengunjung } \\
\text { - Masyarakat } \\
\text { Desa } \\
\text { Mengkatip }\end{array}$ & $\begin{array}{l}\text { Membeli produk } \\
\text { hasil bertanam, } \\
\text { Mengawasi dan } \\
\text { menanam bahan } \\
\text { pangan,Memanen } \\
\text { hasil bertanam dan } \\
\text { Menyimpan bahan } \\
\text { pangan }\end{array}$ & $\begin{array}{l}\text {-R. Administrasi } \\
\text { - Product Display } \\
\text { - Farming Area } \\
\text { - Gudang Kering \& } \\
\text { Basah }\end{array}$ & $\begin{array}{l}1 \text { Unit } \\
1 \text { Unit } \\
1 \text { Unit } \\
2 \text { Unit (5x5) }\end{array}$ & $\begin{array}{l}9 \mathrm{~m}^{2} \\
9 \mathrm{~m}^{2} \\
288 \mathrm{~m}^{2} \\
50 \mathrm{~m}^{2}\end{array}$ \\
\hline & \multicolumn{5}{|c|}{ TOTAL + SIRKULASI 30\% } & $356 \mathrm{~m}^{2}$ \\
\hline \multirow[t]{2}{*}{ 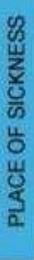 } & UNIT KESEHATAN & $\begin{array}{l}\text { - Pasien } \\
\text { - Pengunjung } \\
\text { - Dokter } \\
\text { - Apoteker } \\
\text { - Staff }\end{array}$ & $\begin{array}{l}\text { Check-up, } \\
\text { Merawat, } \\
\text { Beristirahat, } \\
\text { Meracik Obat, } \\
\text { Menunggu, } \\
\text { Berkonsultasi, } \\
\text { Administrasi }\end{array}$ & $\begin{array}{l}\text { - R.Tunggu } \\
\text { - R.Administrasi } \\
\text { - R.Dokter } \\
\text { - R.Obat } \\
\text { - R.Perawatan } \\
\text { - Tollet }\end{array}$ & $\begin{array}{l}1 \text { Unit } \\
1 \text { Unit } \\
1 \text { Unit } \\
1 \text { Unit } \\
2 \text { Unit } \\
(3 \times 3) \\
2 \text { Unit }\end{array}$ & $\begin{array}{l}12 \mathrm{~m}^{2} \\
9 \mathrm{~m}^{2} \\
16 \mathrm{~m}^{2} \\
9 \mathrm{~m}^{2} \\
18 \mathrm{~m}^{2} \\
9 \mathrm{~m}^{2}\end{array}$ \\
\hline & \multicolumn{5}{|c|}{ TOTAL + SIRKULASI 30\% } & $94,8 \mathrm{~m}^{2}$ \\
\hline
\end{tabular}

Sumber:Penulis, 2020

\section{Sintesa :}

a. Ruangan dibuat dengan konsep terpusat, dimana fasilitas penunjang yang ada dibuat mengelilingi Balai Adat

\section{Tanggapan Bangunan Terhadap Kawasan}

Program ruang yang dibuat didalam site dikelompokkan menjadi tiga kegiatan yang mencangkup konservasi, agroforestry hutan, pasar komoditas, hunian, dan fasilitas umum. Program ini dimaksudkan untuk menjawab masalah deforestasi yang melibatkan ke-3 subyek pelaku, program ini mencangkup kegiatan konservasi,preservasi dan restorasi pada Kawasan hutan yang nantinya hasil hutan ini dapat menjadi katalis antara kegiatan masyarakat Dayak dengan kegiatan komersil sehingga hubungan mutualisme dapat tercapai. 


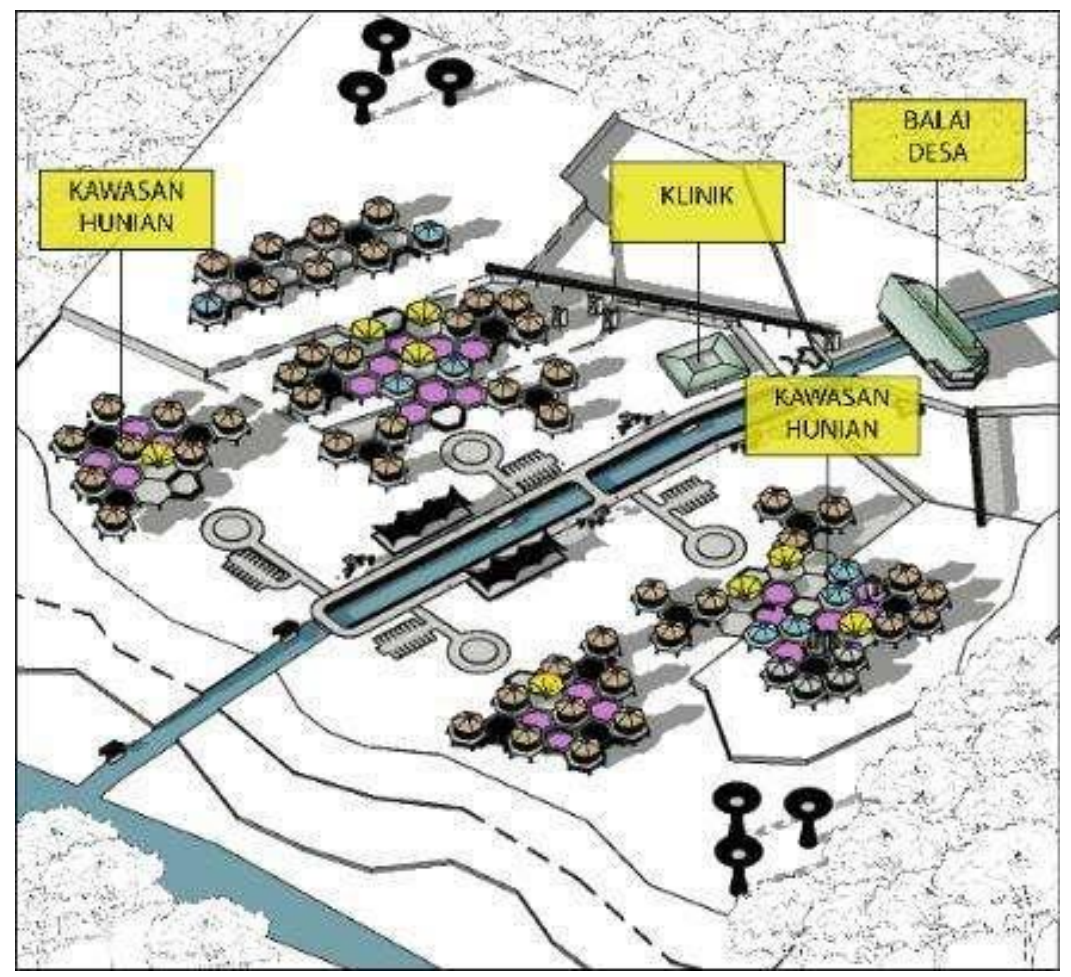

Gambar 5. Ilustrasi penempatan proyek berdasarkan fungsi Sumber:Penulis, 2020

Kegiatan pendukung seperti konservasi dan agroforestry terletak di bagian selatan Site,dimana kegiatan ini berdekatan dengan sungai Barito. Area bertanam ini memerlukan area yang luas dikarenakan fungsinya yang dibagi menjadi dua, dengan memanfaatkan dan memaksimalkan KDH sebanyak $40 \%$, area ini kemudian dibantu dengan sumber air yang berasal dari sungai dan air hujan baik untuk irigasi ataupun keperluan lainnya. Hasil yang didapat dari hutan kemudian dijual di pasar komoditas untuk memenuhi kebutuhan ekonomi atau sandang, pangan dan papan.

Hasil organisasi ruang yang sudah dibentuk kemudian diolah menyesuaikan standar ergonomis dan hasil dari studi preseden yang sudah dikaji. Site plan bangunan kemudian dirancang menyesuaikan dengan kondisi tapak yang berkontur serta memasukkan beberapa elemen dari kebiasaan bagaimana suku Dayak berhuni, yaitu dengan menempatkan hunian secara linear.Konsep desain dengan pendekatan terhadap subyek yang terlibat kemudia juga diterapkan dalam wujud ruang hasil akulturasi antar budaya. Massa hunian sendiri dibagi menjadi 2 tipe yaitu 1 dan 2 kamar. Massa hunian dalam proyek dihubungkan menjadi satu kesatuan menggunakan modul berbentuk hexagonal, lalu dibentuk menjadi sebuah grup kecil berisikan 3 sampai 4 rumah yang nantinya kelompok hunian ini akan berbagi area komunal. 


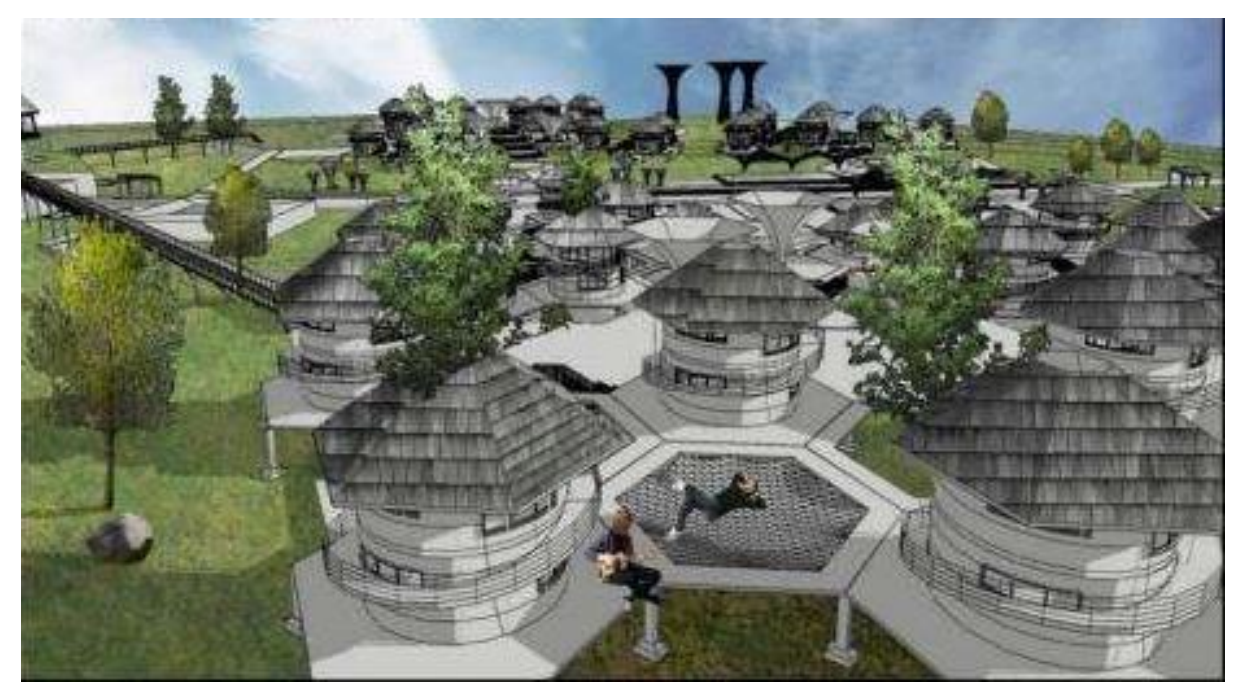

Gambar 6. Ilustrasi kelompok hunian Sumber:Penulis, 2020

\section{Penerapan sistem keberlanjutan dalam Proyek}

System yang digunakan pada proyek memanfaatkan energi terbarukan untuk menciptakan lingkungan yang lebih resilient terhadap permasalahan ekologi dan social. System ini bertujuan untuk menciptakan Kawasan yang mandiri akan kebutuhan air dan listrik, serta mengurangi penggunaan bahan bakar fossil dan memaksimalkan penggunaan air hujan. Penggunaan green design system ini menjadi elemen utama untuk memperbaiki dan merestorasi lingkungan.'
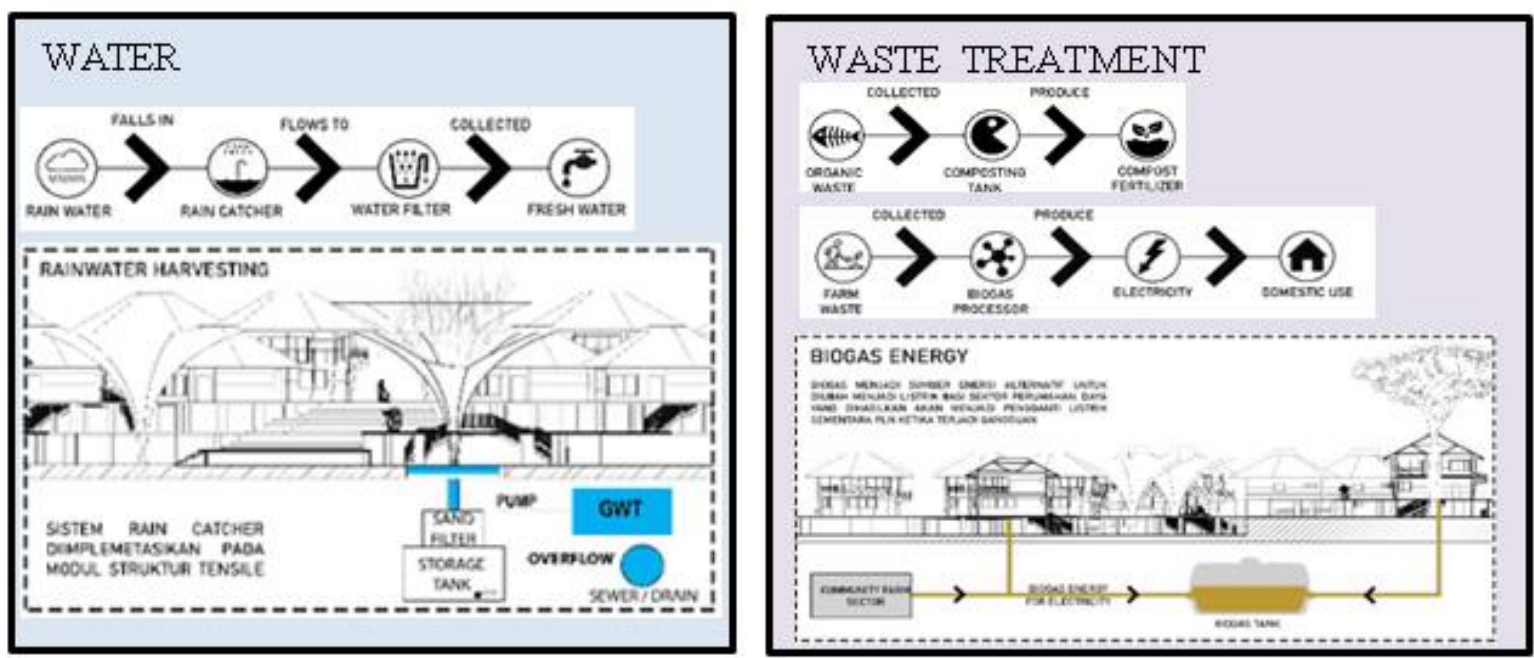

Gambar 7. Penerapan system keberlanjutan dalam proyek Sumber:Penulis, 2020 


\section{KESIMPULAN DAN SARAN \\ Kesimpulan}

Diciptakannya proyek $d$ welling di hutan ini tentunya harus memperhatikan kondisi dan dampak yang diberikan ketika membangun proyek,namun dengan memanfaatkan bahan material dari daerah lokal diharapkan dapat membantu menjaga kelestarian lingkungannya. Pengaplikasian konsep hidup sambil menurunkan Global Warming pada bangunan, beserta penerapan program-program mengenai penghijauan dalam proyek dapat dijadikan sebagai percontohan pada dwelling yang menekankan jiwa penghijauan dalam proyeknya, sehingga di masa depan selain kebutuhan pangan dan papan permasalahan ekonomi di kawasan proyek juga tidak menjadi sebuah permaslahan.

\section{Saran}

Penulis menyadari bahwa makalah yang dibuat masih jauh dari sempurna dan masih perlu pengembangan mengenai Pembuatan kawasan hunian di tengah-tengah hutan seperti :

- Perlu riset dan pengembangan lebih lanjut lagi mengenai larangan-larangan pada bangunan yang akan dibuat berdasarkan permasalahan sos-bud.

- Pembuatan akses untuk mencapai kawasan yang ada di hutan.

- Desain yang masih bisa dibuat lebih menarik.

\section{REFRENSI}

Annual Forest Cover loss in Indonesia,diunduh 15 Agustus 2020, https://bit.ly/Indonesia_2015

CIFOR - Dialog Hutan (The Forests Dialogue/TFD), Maret 2014,Tata Guna Lahan di Kalimantan, diunduh 12 Agustus 2020, https:// Theforestsdialogue.org

EMISI KARBON INDONESIA THN 2020, diunduh 7 agustus 2020, https://climateactiontracker.org/countries/ indonesia/

Heidegger, M. (1971). Building Dwelling Thinking. From Poetry, Language, Thought, translated by Albert Hofstadter. New York: Harper Colophon Books. http://home.lu.lv/ ruben/Building\%20Dwelling\%20Thinking.htm

Indonesia's Second Bienial Update Report, 2018, diunduh 1 Agustus 2020, Indonesia. Biennial update report (BUR). BUR 2. | UNFCCC

Lynch, K. (1960). The Image Of The City. Massachusetts:The MIT Press.

Norberg-Schulz, C. (1984). The Concept Of Dwelling. New York: Rizzoli.

Penyebab utama deforestasi dan degradasi lahan, diunduh 4 agustus 2020, https://www.forestdigest.com/

Peta admiinistrasi Barito Selatan, diunduh 20 Agustus 2020, https://petatematikindo.wordpress.com/tag/barito-selatan/

Peta deofrestasi di Mengkatip, diunduh 10 Oktober 2020, www.globalforestwatch.org

Produksi Emisi dari Deforestasi dan Degradasi hutan, diunduh 1 Agustus 2020,

Emisi Karbon Deforestasi dan Degradasi Hutan Berkurang (forestdigest.com) https://nunatsiaq.com/wp content/uploads/2015/05/top_10_emitters_570.jpg

Sharr, A. (2007). Heidegger for Architects: Building Dwelling Thinking. London: Routledge.

Sugiyono. (2017). Metode Penelitian Kuantitatif, Kualitatif, dan R\&D. Bandung: Alfabeta, CV.

UNDP, Sustainable Development Goals, diunduh 8 Agustus 2020, Sustainable Development Goals | UNDP

Validnews.id.(2018, July 20). Emisi Gas Rumah Kaca Global, IPCC 2014. Diunduh 1 Agustus 2020, MENDORONG EBT UNTUK MENGURANGI PEMANASAN GLOBAL (validnews.id) 